Geopolítica(s) Revista de estudios sobre espacio y poder ISSN: 2172-3958

https://dx.doi.org/10.5209/geop.69347

\title{
Aesthetic Separation / Separation Aesthetics: The Pandemic and the Event Spaces of Precarity
}

\author{
Sam Okoth Opondo y Michael J. Shapiro ${ }^{2}$
}

Recibido: 8 de mayo de 2020 / Aceptado: 10 de mayo de 2020

\begin{abstract}
The consensual and dissensual modes of separation above alert us to how the COVID-19 pandemic has turned the present into a time of intense separation, one of which is between those bodies marked as essential versus non-essential, those that have 'pre-existing conditions' and those without, and those located in precarious zones of abandonment, congestion, and containment, and those that, owing to prevailing economic distancing and apartness, can practice a life of social distancing. Not only does this highlight how some lives and livelihoods are deemed essential yet disposable, we also come to see which forms of loss or even death are considered grievable and which ones are subjected to the sacrificial calculus and discourses of necessity. Noting the dynamics associated with that emerging division, while at the same time reviewing a series of texts featuring aesthetic separations, our essay proceeds through a series of 'ante-metabolic spins' that invite 'us' to think critically about the political implications of aesthetic separations and separation aesthetics.
\end{abstract}

Keywords: COVID-19 pandemic; essential lives; social distancing; grief; separation aesthetics.

\section{[es] Separación estética / Estética de separación: la pandemia y las actividades de los espacios de precariedad}

Resumen. Los modos de separación consensuales y disensuales anteriores nos alertan sobre cómo la pandemia de COVID-19 ha convertido el presente en un momento de separación intensa, uno de los cuales es entre aquellos cuerpos marcados como esenciales frente a los no esenciales, entre aquellos que tienen "pre-condiciones existentes" y aquellos que no existen, y entre aquellos ubicados en zonas precarias de abandono, congestión y contención, y aquellos que, debido al distanciamiento económico y la separación existentes, pueden practicar una vida de distanciamiento social. Esto no solo resalta cómo algunas vidas y medios de subsistencia se consideran esenciales pero desechables, sino que también vemos qué formas de pérdida o incluso muerte se consideran lamentables y cuáles están sujetas al cálculo de sacrificio y los discursos de necesidad. Al observar la dinámica asociada con esa división emergente, al mismo tiempo que revisamos una serie de textos con separaciones estéticas, buscamos avanzar a través de una serie de "giros ante-metabólicos" que "nos" invitan a pensar críticamente sobre las implicaciones políticas de las separaciones estéticas y la estética de separación.

Palabras clave: pandemia de COVID-19; vidas esenciales; distanciamiento social; duelo; estética de separación.

1 Departments of Political Science and African Studies, Vassar College.

E-mail: saopondo@vasser.edu

2 Department of Political Science University of Hawaii, Manoa.

E-mail: shapiro@hawaii.edu 
[pt] Separação estética / Separação estética: a pandemia e as atividades dos espaços de precariedade

Resumo. Os modos de separação consensual e disensual anteriores nos alertam sobre como a pandemia da COVID-19 transformou o presente em um momento de intensa separação, um dos quais é entre os corpos marcados como essenciais versus os não essenciais, entre aqueles que eles têm "condições pré-existentes" e aqueles que não existem, e entre aqueles localizados em zonas precárias de abandono, congestionamento e contenção, e aqueles que, devido ao distanciamento econômico e à separação existentes, podem praticar uma vida de distanciamento social. Isso não apenas destaca como algumas vidas e meios de subsistência são considerados essenciais, mas descartáveis, mas também vemos quais formas de perda ou mesmo morte são lamentáveis e quais estão sujeitas ao cálculo do sacrifício e discursos de necessidade. Ao observar a dinâmica associada a essa divisão emergente, ao mesmo tempo em que revisamos uma série de textos com separações estéticas, buscamos avançar através de uma série de "voltas pré-metabólicas" que "nos convidam" a pensar criticamente sobre as implicações políticas das separações estéticas e a estética da separação.

Palavras-chave: pandemia da COVID-19; vidas essenciais; distanciamento social; luto; estética de separação.

Sumario. 1. The Discursive Spaces of the Pandemic. 2. Mise en scène: New Borders/ Exhausted Bodies. 3. "Night People". 4. Hospitality/ Hostility Redux: Stephen Frears's Dirty Pretty Things (2002). 5. Hotel/ Hospital Space. 6. The Welcomed and UnWelcome Intrusions in Socio-Political Space. References.

Cómo citar: Opondo, S. O., y Shapiro, M. J. (2020). Aesthetic Separation / Separation Aesthetics: The Pandemic and the Event Spaces of Precarity. Geopolitica(s). Revista de estudios sobre espacio y poder, 11 (Especial), 223-238.

\section{The Discursive Spaces of the Pandemic}

The jump of the SARS-CoV-2 virus from non-human to human beings, and thence the transmission from person-to-person via respiratory droplets and contaminated surfaces generated a new consciousness of the body, touch, connection, and contagion. In this new spatial reality, we are reminded of the eerily uncanny words of Dr. Erin Mears (Kate Winslet), a CDC Epidemic Intelligence Service Officer in Steven Soderbergh's film Contagion (2011) who, in a briefing with public officials from Minnesota about the outbreak of the fictional MEV-1 virus informed them that the respiratory disease may be spread through droplets or fomites:

The average person touches their face two or three thousand times a day ... Three to five times every waking minute. In between, we're touching door knobs, water fountains, elevator buttons and each other. Those things become fomites.

Contagion's affective legacy for the COVID-19 pandemic is evident. The heroic and sacrificial work of public health officials and infectious disease scientists are highlighted as the bodily touch and the surfaces that we habitually touch is presented as potentially fatal. As the camera zooms in or lingers over surfaces, bodies, and objects, the cinematic optic register is translated into a haptic one drawing the viewers' attention to the everydayness of touch. Given that the viewership of Con- 
tagion has increased in an age where the reel pandemic is said to have resonances with the 'real' COVID-19 pandemic of today (with the film being highly recommended for lockdown viewing), its focus on fomites and surfaces offers an opportunity for an alternative figuring of the pandemic. One that reads its surfaces and pays attention to the workers who do the cleaning protocols or other ancillary work in hospitality spaces that are central to the spread and containment of the virus. Turning our attention to these haptic topographies and the forms of touch or untouchability that they bring together calls out attention to other texts and contexts that serve as the mise en scène for our immunitary present in ways that exceed the pandemic event.

While an epidemiological reading of the present has taken center-stage due to the death-deploying capacities of the pandemic, we begin our analysis with a reading of aesthetic separations/ separation aesthetics drawing upon Achille Mbembe's "reverse reading of our present" which involves a "break with the spirit of our times" and the closures and demarcations that are part of this 'exit from democracy' and the 'formation of a society of enmity.' (Mbembe, 2019, p.9). In his sociodiagnosis of the present, he notes that "more than about difference, the era is thus about the fantasy of separation, and even extermination." The desire for a world devoid of sharing, he goes on to state, is "gradually displacing the proposition of universal equality" that had been mobilized to contest the vision of a world without others. This scission renders some people "useful" while others are considered "useless" not according to the colonial re-peopling of the earth with superfluous men, but according to the "capacity to deploy a labor force" (ibid., p.12).

The "history of modern democracy," Mbembe illustrates, involved a "twofold movement of internal consolidation and expansion across the seas." That gave us a democracy with "a solar body and a nocturnal body" the latter finding its manifestation in the "colonial empire and pro-slavery state." (ibid., p.22). Today, the nocturnal face of democracy and the great fear of the return or eruption of the violence that was exteriorized or that which lays latent in democracy manifests itself through calls for sacrificial 'herd immunities', 'racialized geographies of blame,' armed demand for the old order which serves as a reminder of the violence that exists and a threat of that which is yet to come (ibid., p.27; Benton, 2020). That fantasy of separation exists side-by-side with a 'structural proximity' where there is no longer any outside as such. Nevertheless, the "community of separation" persists through practices of "exception and its corollary, immunity," which are finding new articulations through cellular technologies, conspiracy theories, and sovereign practices that facilitate the merging of capital and animism alongside the proliferation of paranoid dispositions (Mbembe, 2019, p.39). This raises new questions for life and humanity in an "era of swarming, proliferation, and grafting of everything onto everything else" where it is impossible to "sanctuarize' ones home by fomenting chaos and death far away, in the homes of others." (ibid., p.40). The 'de-westernization' of the world that these changes imply also generate speculations about the connectivities and collectivities to be composed and the forms of solicitude that become adequate in the city and even the planet of the future where we are "condemned to live in our exposure to one another, sometimes in the same space." (ibid., p.40).

To elaborate the significance of Mbembe's observations about our present era, we can heed some insights from Jacques Rancière who points us in a radically dif- 
ferent direction from the 'exit from democracy' or the Hatred of Democracy that privileges individual consumers, props up oligarchies, and maintains a state that dismantled common institutions of welfare which is then entrusted with the work of distributing assistance to those who it had already dispossessed (Rancière \& Corcoran, 2014, p.83). Rather than an order of apartness, where each body is accorded its proper place and function, or the undertaking to fix the distribution of places and competences, Rancière explores the paradox of "being together apart" which is derived from a statement he borrows from the poet Mallarmé (Rancière \& Elliott, 2011, p.51). He goes on to elaborate on a second proposition based on his reading of the work of a French group of artists (Urban Encampment / Campement Urbain) whose project $I$ and $U s$ constructs a place of solitude such that "an aesthetic place appears as a space for engaged art" that has the capacity to "pull the question of community out of its ethnic configuration." (ibid., 2011, p.53). His final philosophical proposition points to the political import of art in the "transformation of the sensory fabric of the being together" which ties humanity together. This dissensual aesthetic community emerges when a dissensual figure superimposes one "sensorium on another sensorium" in ways that create an aesthetic break, which is in effect, a break with the regime of representation (ibid., p.59). Unlike the separation fantasies that Mbembe is critical of, aesthetic separation interrupts the order that seeks to assign bodies, borders, and things a fixed or specific function or destination according to the dominant regime of intelligibility (ibid., p.70).

The consensual and dissensual modes of separation above alert us to how the COVID-19 pandemic has turned the present into a time of intense separation, one of which is between those bodies marked as essential versus non-essential, those that have 'pre-existing conditions' and those without, and those located in precarious zones of abandonment, congestion, and containment, and those that, owing to prevailing economic distancing and apartness, can practice a life of social distancing. Not only does this highlight how some lives and livelihoods are deemed essential yet disposable, we also come to see which forms of loss or even death are considered grievable and which ones are subjected to the sacrificial calculus and discourses of necessity. Noting the dynamics associated with that emerging division, while at the same time reviewing a series of texts featuring aesthetic separations, our essay proceeds through a series of 'ante-metabolic spins' ${ }^{\text {'3 }}$ that invite 'us' to think critically about the political implications of aesthetic separations and separation aesthetics. With that as prelude, we return to the mediations that create alternative versions of the pandemic event by paying attention to extra-pandemic event spaces.

\section{Mise en scène: New Borders/ Exhausted Bodies}

In an account that delineates the "contradiction and dialectic between the neoliberal bourgeoisie and [these] exhausted superfluous bodies," Françoise Vergès illustrates how separations and entanglements manifest in the "new borders that have been drawn between cleanliness and dirtiness in an age in which concerns are growing

3 We borrow the play on the 'antemetabolic spin' from Mowitt (2000, p.272). 
for clean air, clean water, clean houses, clean bodies, clean minds, and green spaces." (Vergès, 2019). The ideology behind the concern for "a healthy/powerful body and mind" serves a biopolitical function while at the same time feeding "a desire to outlive human constraints." While the language of care and cleanliness underwrites the desire for a healthy body and mind as articulated in wellness and self-care practices and the industries that prop them up, what is less evident is the precarious care-work and precarious labor that remains indispensable to the functioning of these spaces of care and work. This nocturnal labor, even when physically visible, is for the most part superfluous and while laborers remain essential to the care industry or the protocols of disinfection and deep cleaning today, they are also highly disposable or replaceable. Vergès puts it quite well when she states:

Every day, in every urban center of the world, thousands of black and brown women, invisible, are "opening" the city. They clean the spaces necessary for neo-patriarchy, and neoliberal and finance capitalism to function. They are doing dangerous work: they inhale toxic chemical products and push or carry heavy loads. They have usually travelled long hours in the early morning or late at night, and their work is underpaid and considered to be unskilled. They are usually in their forties or fifties. A second group, which shares with the first an intersection of class, race, and gender, go to middle class homes to cook, clean, and take care of children and the elderly, so that those who employ them can go to work in the places that the former group of women have cleaned (ibid).

While much of the reading of the pandemic attends to the biopolitical and necropolitical regimes of governance, the pandemic has added a level of precarity to these already precarious lives that are at once biopolitical and biocolonial. The frontloading of essential workers within a national imaginary that invokes war metaphors such as the ones used to stigmatize the same workers under different circumstances is telling. To address this situation, we turn first to a fictional rendering of a segment of the invisible "thousands of black and brown women" who (as Vergès puts it) "clean the spaces necessary for neo-patriarchy, and neoliberal and finance capitalism to function" and the nocturnal lives, economies, and spaces that are part of their 'normal' way of being as well as the dynamics of community, immunity, hospitality, and hostility that they engender. Rather than focus on an immunitary reading of the foreign body (as pathogen) through one of the most significant curative spaces - the hospital - our analysis proceeds through an aesthetic reading of hotel/hospitality spaces, hospitality/hostility apparatuses, and the precarious foreignized body of the migrant.

Doubtless, hospitals and hotels are etymologically connected to hospitality/hostility. What is less recognized is how these hospitality apparatuses also highlight the cultures of the home, sovereignty, reception, invitation, and co-habitation. With the increasing commodification of hospitality, privatization of healthcare, and demonization of foreign bodies, sites of hospitality and communion become hostile and immunitary through "privatizing and familialist reactions, that widen the ethnocentric and nationalist and xenophobic circle." (Derrida \& Dufourmantelle, 2000 , p.53). Beyond their mutual etymological connection to the space that welcomes foreigner / visitor (hospes), hospitals and hotels are both meta-logistical sites where the logics of logistics and lodging intersect in ways that bring together 
multiple visitors, migrant workers, management methods that enforce and reserve 'rights of admission', access, accommodation, and precarity. During times of crises such as the current pandemic, accelerationist war metaphors are mobilized and caregivers projected as either soldiers or enemies, essential and non-essential workers, in ways that remind us that logistics is originally "the art of moving war material and quartering troops, is about organizing and sustaining supply chains, but it also suggests the practices of lodging, accommodation, and shelter as well as moving whatever materials are needed to sustain these activities." 4 The traffic in bodies, signs, and affects below are an attempt to look slowly and with more attention to the "daily traffic of codes and commodities" as well as in "the movement of materials and people" that are central to the aesthetic separations that mark the dynamics of immunity/community, hospitality/hostility, and humanity/superfluity (Rinelli \& Opondo, 2013).

\section{3. "Night People"}

The precarious lives to which Vergès refers are rendered in intimate portraits and scenarios in Edna O'Brien's novel The Little Red Chairs (a media genre that sees the world more patiently and in a more socially contextualized way than most news media). The plot of the novel re-invents Radovan Karadžić, the architect of the Bosnian genocide as a character hiding in a small Irish village, where he exploits local vulnerabilities (thus engaging in a softer violence). Using the name Dr. Vladimir Dragan, he opens a holistic healing and sex therapy office and has an affair with a young woman, Fidelma McBride, who is vulnerable because she is unhappily childless and in a failing marriage. While the most dramatic part of the plot is about Karadzic/Dragan's apprehension and detention in The Hague awaiting trial for war crimes, the part of the novel relevant to our analysis takes place in London, where Fidelma goes in exile, having become a pariah in her village, after her affair becomes known. Her entry into London is as a homeless person, where initially she encounters others in that condition, e g., a war refugee from Sierra Leone she meets in a housing queue. He's a man with a "black patch over his eye, talking ceaselessly" and saying "come back to the city, where I know no one and do my hating alone." (O'Brien, 2015, p.157).

Once housed, she is offered hospitality by her future landlady, Jasmeen (herself once a refugee from Uganda who has a soft spot for Irish, having been helped by an Irish woman, Maureen when she first arrived). In charge of finding accommodations for homeless families. Jasmeen had learned enough English to leave a job as a chambermaid (ibidem). Fidelma's flat is in a district where her neighbors have also left precarious situations. For example, the man next door from Zimbabwe, a war victim with injuries that impede his walking. Living on the margins of London, well out of the central tourist section where people's lives - both locals and tourists - are more carefree, Fidelma begins connecting with marginalized "night people" [office cleaners], many of whom are one step away from ghosts and strangers to

4 The term logistics is derived from the French logistique, and loger, meaning "of supplies" and "to quarter." See Luke (2003, p.159). 
each other yet: "They all carried memories and the essence of their first place, known only to them" (ibid., pp.175-176).

After Fidelma picks up a night cleaning job, she meets "Bluey" from Mozambique with whom she is able to share stories (ibid., p.173). Later when Fidelma is passed over for another job she's seeks, Bluey tells her, "Forget it ... As a night cleaner you are supposed to be invisible. You do not exist as a person; you are there to work and not to blab" (ibid., pp.220-221). While the supervisors in the building where she cleans are hostile, abusive, and racist, she finds solace at a refugee center among people who, like her on her entry into London, have experienced themselves as "nobodies, mere numbers on paper or computer, the hunted, the haunted, the raped, the defeated, the mutilated, the banished, the flotsam of the world, unable to go home, wherever home is" (ibid., p.203). Eventually however, London becomes home. Thanks to the solidarity and mutuality she experiences at the center (among those who are apart together), Fidelma comes to live for "these encounters, often in freezing cold, [which] softened the stone in her heart" (ibid., p.185).

In the current quarantining imperatives, such places of solidarity and sanctuary are unavailable to those who need the care and emotional support that O'Brien's fictional refugee center supplies. At the same time, that same population of migrants and refugees are disproportionately located in jobs regarded as "essential" for example those who work in the care homes, hospitals, meet packing plants and other places with a high risk of infection, currently depleting both the population of elderly residents and staff. Edified by O'Brien's intimate view of the precarious lives of "night people" in the London scene, in what follows we look outside of the dominant macropolitical policy issues that the pandemic presents local governance, as they manage the trade off's between commerce and mortality and focus on a micropolitical level to examine the lives that are most precarious yet superfluous.

\section{Hospitality/ Hostility Redux: Stephen Frears's Dirty Pretty Things (2002)}

O'Brien's novel tracks very closely with Stephen Frears film Dirty Pretty Things (2002), which is also set in London and treats moments of solidarity among an immigrant population, many of whom, are exploitable "night people" who work illegally. Early in the film, one of them, Juliette (Sophie Okonedo), a sex worker who meets her clients in the hotel at night, says that she "doesn't exist," a remark comparable to one by Fidelma's "night person" friend, Bluey, who says to her (after she's denied something at work), "Look, forget it....as a night cleaner you are supposed to be invisible. You do not exist as a person" (O'Brien, 2015, pp.220221).

Juxtaposing secure and insecure bodies in contemporary London's hospitality industry, Dirty Pretty Things dwells on the difference between touristic central London and its more impoverished, immigrant-inhabited, South London area. As a drama, the film has two of the insecure bodies threatened to have their illegal status exposed unless they cooperate in an illegal organ-harvesting and selling enterprise. Like Fidelma and her co-workers in O'Brien's novel, Frears's main protagonists, the threatened refugees, a Nigerian Doctor, Okwe (Chiwektel Ejiofor) and a Turkish hotel worker, Senay (Audrey Tautou) support each other. With the help of a 
group of marginalized people - the sex worker Juliette, Ivan (Zlatco Buric) an Eastern European doorman, and Guo Yi (Benedict Wong), a Chinese immigrant who works in a morgue - they become transfigured from victims into effective political subjects. Assisted by his friends, rather than extracting Senay's kidneys in exchange for passports, Okwe drugs the organ trade entrepreneur, the hotel manager Senior Juan (Sergei Lopez), harvests his kidney, sells it, and flees from London back to Nigeria while the emancipated Senay heads to New York.

As a film, Dirty Pretty Things thinks primarily with what Andre Bazin calls "image-facts," such that its London is composed by juxtaposing in its montage of scenes a richly ornate hotel lobby on the one hand and a sweat shop with immigrant labor, and a taxi business run by immigrants on the other (Bazin, 1971). Dirty Pretty Thing's image narrative contrasts with the form of O'Brien's novel (its cinematic qualities notwithstanding) which thinks with literary vehicles or what Roland Barthes calls "word-thoughts" (Barthes, 1977). In both texts, we come to see not only the biopolitical but also the biocolonial relations through which "vulnerable third world people who, driven by the stringencies of poverty, illness and/or immigration, exchange their bodily integrity for the possibility of improved survival" (Stein, 2010, p.101). As Rachel Stein illustrates, this radical commodification of third world bodies to be consumed by wealthier first world citizens ranges from illicit organ harvesting from migrants in exchange for papers to experimental imaginaries and practices such as those foregrounded by French professors Jean-Paul Mira and Camille Locht who suggested that new COVID-19 vaccines be tested in Africa. Given its gendered dynamics, sexual coercion is a key component of these biocolonial relations (Stein, 2010, p.112).

Through the amplification of nocturnal lives and practices that take place or go through urban nodal points such as hotels, mortuaries, taxi offices, hospitals, and airport exit points, the disempowered migrants become effective political subjects. As thresholds, these points of encounter are at once terminal points and portals. They are spaces where one's arrival and survival in the city is mediated without any guarantees while the desire to thrive, can in itself impede one's chances of survival. Telling in that respect, Dirty Pretty Things offers us an intimate view of commodified hospitality and circuits of exchange such that Shital Pravinchandra sees the hotel and modes of precarity as well as organization by those operating out-of-sight as offering "a paradigm for this world" in ways that the camp does for theorists like Giorgio Agamben (Pravinchandra, 2013, p.45). To grasp the way Frears's film intervenes in the politics of migrant precarity and the paradigm that it supplies (in this time of pandemics), we suggest heeding what has been referred to as "hotel geopolitics," which in the case of Frears's film drama involves a micropolitics of the way hotel architecture organizes the dynamics of inter-personal space which typically contains among modernity's most stark separations, that between the guests and the lower level staff positions as well as the vast logistical apparatus that connects hotels to global points of extraction.

That political dynamic becomes apprehensible when one heeds the disparate flows of bodies into and around hotel space - the surrounding public, the tourists booking rooms, and the hotel's service personnel. The way hotels spatially manage those flows is summarized well by Sara Fregonese and Adam Ramadan (2015): 
The conditional relation of hospitality is manifested within and without the hotel, and represents the defining characteristic of hotel space ... guests are screened, controlled and charged and welcomed into certain spaces: public areas like the entrance hall, reception corridors, elevators, restaurants, and private areas like guest rooms and function rooms. At the same time guests are restricted from accessing other spaces such as service areas [and] the hotel must...maintain a controlled openness to the outside - to the potential customer - while being able to screen, monitor and subtly control those who enter [because] The open door allows the outside inside... (p.794).

The details of that spatial management is a major feature of the Dirty Pretty Things dramatic narrative, which turns its primary architectural protagonist, London's fictive Baltic Hotel, into a complex event space in which, as the film narrative proceeds, is transfigured from a space of control and coercion to one of dissensual empowerment. Because the camera lingers on London's buildings while following the fates of its characters, the film is best summarized as a story of bodies and buildings. It opens and closes at one of London's Heathrow International Airport's terminals where at the outset, Okwe is soliciting passengers for the cab he drives during the day and in the conclusion is there to see his friend Senay off as she departs for the U.S.

The other important buildings in the film - aside from the Baltic Hotel where Okwe works as a night clerk and Senay (early in the film) works as a maid - are Okwe's cab company run by a Caribbean immigrant, a morgue, where Okwe's friend Guo works, an apartment which he shares with Senay (they use it in separate shifts), a sewing sweatshop where Senay is sexually exploited later in the film, and a hospital, where Okwe sneaks in disguised as a janitor whose social invisibility enables him to steal medicines, first to help refugees without access to health care even after having sold their kidney to get citizenship, and later to get them for a nephrectomy as part of the hotel manager Senior Juan's (Sergi López) aka Sneaky's illegal organ-harvesting business (which he runs in the hotel at night).

The film drama begins when Okwe discovers a human heart clogging one of the hotel toilets after being called to fix the plumbing problem in room 510 by the sex worker Juliette (Sophie Okonedo). When he informs Senior Juan about the heart in the toilet and asks him to call the police for the heart is evidence that someone somewhere is dead, his boss offers to call the police provided Okwe speaks to them. Because of his illegal status he cannot do anything about his discovery and Senior Juan offers him some advice based on the pedagogy of the hotel; "You will learn Okwe. The hotel business is about strangers. And strangers will always surprise you, you know? They come to hotels at night to do dirty things. And in the morning, it is our job to make things look pretty again."

Like Sr. Juan, Okwe's friend Guo also makes him aware of his precarious situation reminding him that owing to his status, he does not count for much and cannot do much: "Okwe, you are nothing, you have nothing ... just help the people you can." However, Okwe acquires a different subject status once his medical background is discovered by Senior Juan, who offers him and Senay illegal passports (one of Senior Juan's side businesses) in exchange for Okwe's medical service as an organ harvester. Although Okwe initially refuses, he changes his mind when he discovers that Senay is about to exchange a kidney for a passport and that Senior 
Juan has also taken her virginity as part of the deal. While the recognition of Okwe's medical training at both his places of work afford him some room to negotiate his precarious existence, Senay, owing to her status as a refugee woman is subjected to coercive sexual encounters with her employers. First, at the sweatshop where her boss demands oral sex and now at the Baltic Hotel where Senior Juan demands that her virginity, in addition to her kidney be part of the passport deal.

In a change of heart, Okwe offers to perform the surgery himself in order to ensure that Senay is not butchered and demands a new passport and identity for the two of them in return. Impressed by the transformation that now makes it possible for the otherwise ethical Okwe to see things his way, Senior Juan, in an act of recognition of exclaims "So you are human, Okwe!" Presenting the commodification of life and prioritization of one's own interest as that which makes one human. However, instead of harvesting Senay's kidney, Okwe drugs and extracts Senior Juan's, delivers it to a waiting driver in the hotel basement, collects the fee, and along with Senay is driven to Heathrow Airport by Guo, where after he sees Senay off to the US with her illegal passport he calls Nigeria to tell his young daughter he is coming home.

\section{Hotel/ Hospital Space}

As a drama, Dirty Pretty Things illustrates how precarious subjects can forge a temporary oppositional community of sense, which acts effectively to overcome a precarious situation while transfiguring their space of work and life into that of dissensual collaboration. However, we want to focus on the way the hotel, as the primary event space in the film where illegal kidney extraction and 'paper death' takes place, becomes a major protagonist that enables us to discern the politics that underlines the conversion of hotels into refugee holding or accommodation spaces or more recently, into COVID-19 care rooms under the Hotel to Healthcare Concept (H2HC) (Figure 1). As the film illustrates, the H2HC concept which is part of the U.S Army Corps of Engineers (USACE) and the U.S Department of Health and Human Services (HHS) Alternate Care Site (ACS) design initiatives, is the macropolitical instantiation of logics that are already at play within the hospitality/hostility dispositifs that ties spaces of care, superfluous leisure, and hospitality to those of commodification, containment, abandonment, and surplus life (United States Army Corps, 2020).

While the U.S. Army Corps response presents the hotel/hospital conversion as an emergency measure that seems to depart from the norm, the privatization of healthcare, and medical tourism for the rich have for a long time involved the merging of these two entities. Management models touted by the likes of Fred Lee in If Disney Ran Your Hospital emphasize patient experience and patient loyalty in ways that see healthcare as a competitive corporate rather than common good (Lee, 2004). Similarly, the promotion of medical tourism and wellness tourism in Thailand, Switzerland, India, Costa Rica among other destinations is marked by medical clinics surrounded or merged with ancillary and resort-like recovery facilities characteristic of the $\mathrm{H} 2 \mathrm{H}$ model where hotels and hospitals merge their services into a single package for those who can afford them (DeMicco, 2017). 
Figure 1. Plans to convert hotels into care rooms under the Hotel to Healthcare Concept (H2HC)

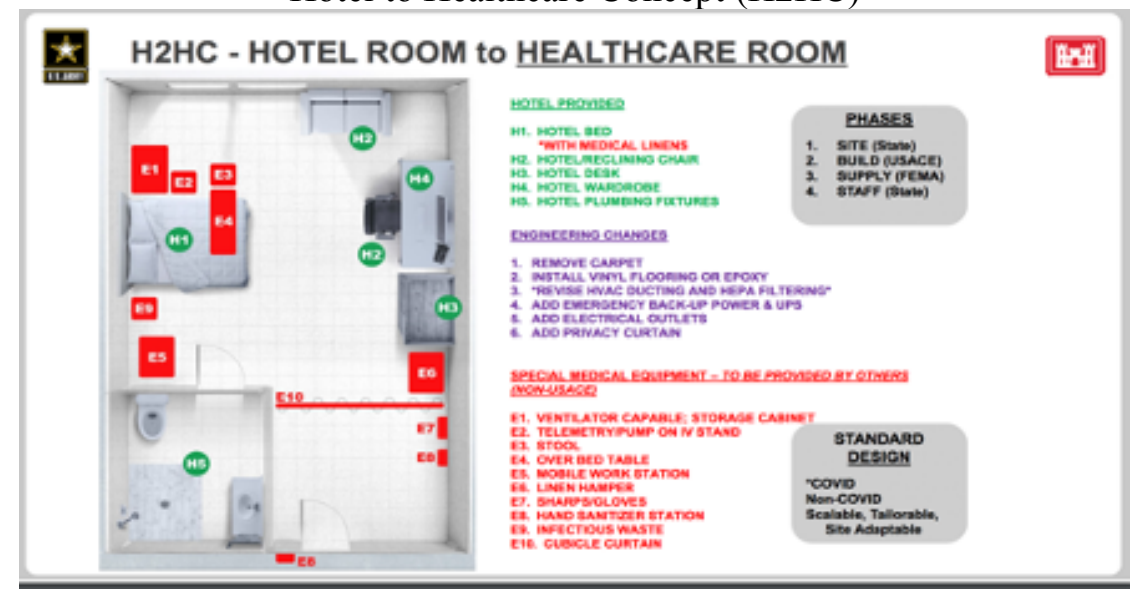

H2HC - TYPICAL FLOOR PLAN
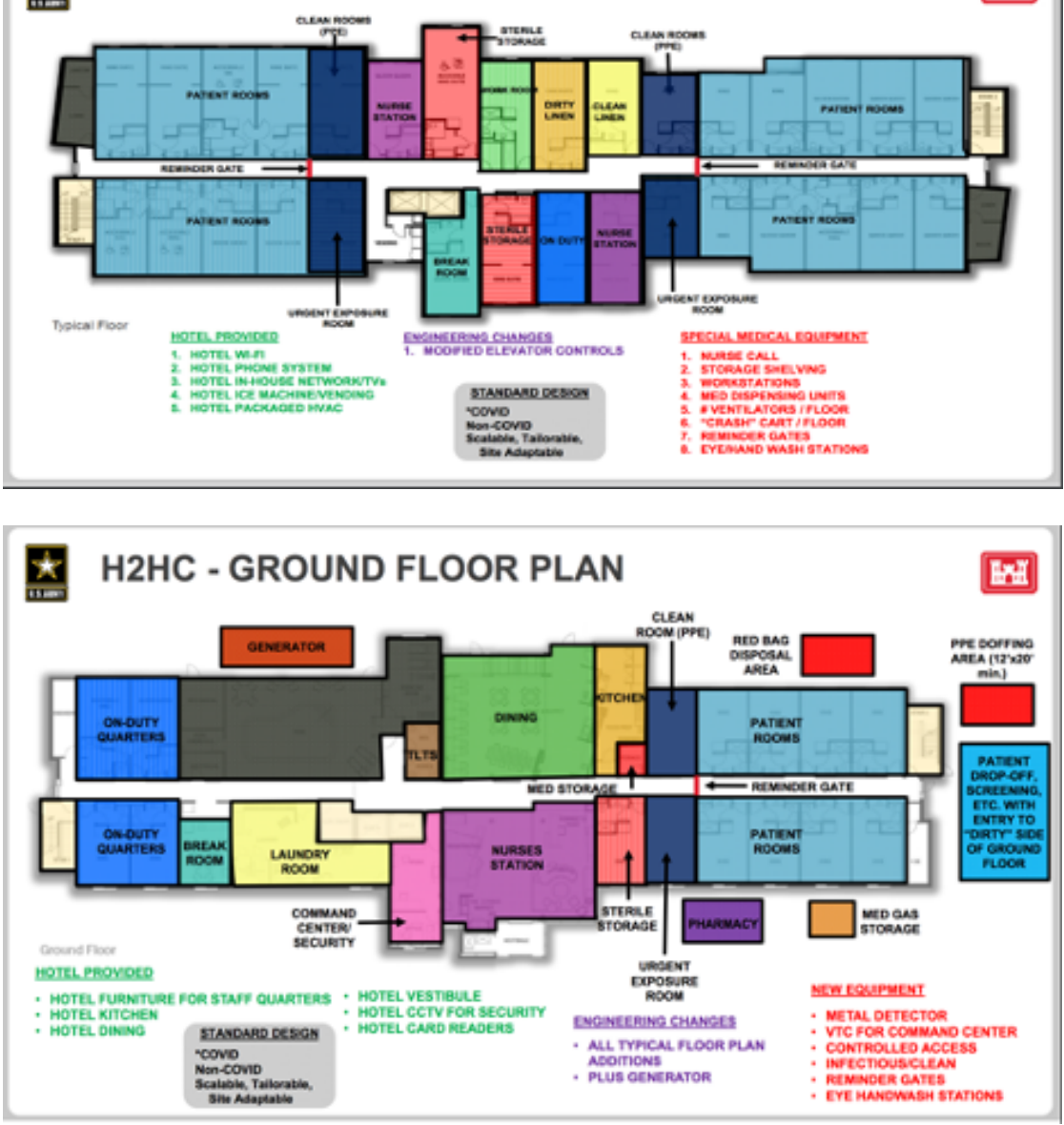

Source: DeMicco (2017). 
The structural violence arising from the capital-mediated merging of hotel and hospital experiences and functions is made apparent in Dirty Pretty Things where 'out-of-place' medical practices are performed on precarious bodies by nocturnal workers in order to feed the demands of a red-market economy. As the camera follows the characters during their fraught exchanges with Senior Juan and the desperate tactics through which they barely avoid two immigration agents who continually threaten them, it also foregrounds the Baltic hotel where one of the rooms is transformed into an operating room for the extraction of organs. There are many framing shots of it from the outside and many framing and tracking shots within that explore its internal partitions, which separate its guest and service areas. Throughout the film, the footage of the hotel emphasizes the way it (like hotels in general) manages the boundaries between open hospitality, superfluity, and security.

The difference between the guest and service areas is color-coded. The guest areas appear in bright red and gold colors while the service areas, the basement where the workers lockers are, and the garage where deliveries are made, are seen through more subdued blue and green filtering. As for how the (largely immigrant hotel staff) appear: "Hotel workers are seen as unseen objects of the multiple desires and fantasies of managers, clients, and co-workers." (McDowell, Batnitzky \& Dyer, 2007, p.3). However, the way they are "unseen" is owed in part to the hotel's social positioning. In contrast with the hotel's guests, whose invisibility (as Siegfried Kracauer famously puts it) is a matter of controlled impression - "The ... hotel lobby ... allows the individual to disappear behind the peripheral equality of social masks..." (Kracauer, 1995, p.181) - the invisibility of the hotel's immigrant workers is a matter of both their inability to rise above the normative standards of social recognition and the spatio-temporal partitioning of the hotel's space.

What goes on in the Baltic Hotel is dramatically different at night versus during the day. One aspect of the difference is a common aspect of hotel experiences; as the sex worker Juliette who meets her clients at night puts it, "doesn't exist" (she is not officially present). More dramatically different with respect of the hotel-asevent-space is Senior Juan's organ harvesting business, which goes on in otherwise vacant rooms at night. It is no coincidence therefore that Juliette (who doesn't exist) is the one who finds the heart to which the body is missing given that these commodified transactions - sex trade and organ trade - take place in the same space.

After Okwe and his team turn the tables and harvest Senior Juan's kidney, a telling follow-up scene takes place: Okwe, accompanied by his operating team descend to the dark, underground parking garage, where they hand over the kidney, packed in ice in a box. The well-dressed white Englishman, accepts it and wonders aloud who they are. Having expected Senior Juan to make the delivery he asks, "How come I've never seen you before." Okwe responds, "Because we are the people you do not see. We clean our room. Iron your clothes, and suck your cocks."

As it has turned out, their invisibility has been, along with the solidarity they have forged, a primary resource. Using their lack of social recognition and the ways in which the built environment has afforded "transitory spatial zones" throughout the city and hidden-from-view areas within the hotel to meet and plan, they are able to evade Senior Juan's coercive power. Ultimately their transfigura- 
tion of a space of hospitality, which the Baltic Hotel features during the day, is a micropolitical event in which the hotel as-as-event-space is reconfigured "from a place of business (whether welcoming touristic bodies or exploiting those of refugee/immigrants) into a space of political engagement" (Shapiro, 2006, p.678).

\section{The Welcomed and UnWelcome Intrusions in Socio-Political Space}

In the reflections above, we present a series of aesthetic texts that enable us to move away from the floating sign that underlines the language of essential and non-essential workers which overlooks other forms of precarity beyond the worker's exposure to disease and the lack of Personal Protective Equipment. Our attention is drawn to 'nocturnal laborers' for whom the pandemic and even the conditions that predate the pandemic intensify their precarity while subjecting them to relationships of predation of one kind or another. By looking at the fear and haterelated affects that the pandemic is amplifying alongside the micropolitical practices of precarious workers that interrupt, connect to, or disconnect with the habitual policing apparatuses, we discern a 'transformed sensation' of the present that questions the functions and sense of community that people are summoned to participate in (Rancière, 2008, pp.4-5). In contrast with the proclamations about consensual suffering bodies, e.g., those who claim that "we are in all this together," while at the same time immunizing themselves from proximate and distant others would, we suggest instead paying attention to the multiple ways of 'being together' some of which call for us to come to terms with the paradox of being 'apart together' that challenges separation fantasies without seeking to "pin people down to their proper places" or bodies to pre-determined functions (Rancière, 2008, p.3).

As has been the case for a politically attuned notion of work, precarity, and sacrifice, leisure, safety and the capacity to distance oneself or even extend life is now politicized with an acute recognition of entanglements between spaces and an awareness of distributions of the sensible. What is revealed is the way "leisure is won on the back of workers." (Rancière, 2004, p.12). Also revealed is the metalogistical and ecological connections between spaces of consumption and those of production, extraction, and waste. Ultimately, our reflections on aesthetic separation / separation aesthetics in the wake of the pandemic seeks to map these dynamics of visibility/ invisibility, community/immunity, hospitality/ hostility that are disclosed when we attend to the multiplication of connections and disconnections between bodies and the distribution of worlds. Even though the contemporary politics of the pandemic has highlighted these connections and generated moments of rupture characterized by local acts of generosity, mutuality, and resistance, the governing logics and allure of resilience often call for an uncritical adaptation to the new conditions, concretization of border or the desire for a return to normalcy characterized by the exit from democracy.

Unlike the current separation fantasies advanced by those who consider themselves to be rights-bearing (and therefore arms bearing) subjects of the political community, and unlike those who seek immunity based on inattention to the lives of others, our attention to aesthetic breaks aims to reveal the rare events that occur when those people who have no proper place in the political community nonethe- 
less partake of that community and interrupt its habitual mode (Ranciere \& Panagia, 2000).

Recognizing the dissensual acts in Dirty Pretty Things arising from the discovery of the heart and with attention to the heart-related problems emerging from COVID-19 (where the main focus has been on acute respiratory distress), we conclude with a reflection on the condition of heartlessness and life-saving intrusion in addition to the general sense of breathlessness that is used to figure the pandemic. Here, Jean-Luc Nancy's meditation on his own heart transplant which he treats as a foreign intruder and develops a metaphoric frame translates well into the situation of the intruding migrant body. The threat of rejection faced by Nancy's "foreign" heart is palliated by an anti-rejection treatment in the form of "immuno-globulin that comes from a rabbit" which "resist the human defense system mechanisms that produce it." He also meditates on the technical and metaphysical adventure that the heart transplant facilitates and the biological community enabled by immunosuppressants like cyclosporine. With the 'intruder' in place, "One no longer knows or recognizes oneself...the empty identity of an "I" can no longer rest in its simple adequation (its "I" = "I"). The threshold between the self and other is breached, when on says "I am suffering" implies that there are two "I"s, each one foreign to the other (yet touching)." (Nancy \& Hanson, 2002, p.12).

In Nancy's case, the problem of rejection of the organ of the other (human) has a medical solution mediated by exposure to the non-human other. His meditation on hospitality and touch encourages us to reflect on the ethic-political stakes of our immunitary present where experimental use of convalescent plasma containing anti-SARS-CoV-19 antibodies can provide a reprieve from a disease that strikes fear in humans everywhere owing to its global reach (pan demos) (Roback \& Guarner, 2020). However, as we know, this common fear of the pathogen remains elusive, impossible, or only possible by metalepsis for some while it is intensified or supplemented by other fears, negative affects, and precarity for others. With the suggestion that persons who have contracted and recovered from COVID-19, or those who in the future will have received the vaccine be given immunity passports, new questions arise about the regimes of governance, immunity, discrimination, hostility/hospitality and the heartlessness that they will generate (Persad \& Emanuel, 2020).

As the pandemic's immunitary regimes intersects with nationalism, the rejection of "foreign intruders" becomes more than a trope. In this case, there is no quick solution (no anti-rejection drug) to palliate the rejection impulse of nativists. Their impulse has historical, ideational and psychological depth. Slavoj Zizek addresses that "depth," suggesting that the imagined bond that holds an ethnic community together, "implies a shared relationship to a thing," and that "national identification" is "sustained by a relationship to the nation qua thing," which alien others cannot adequately grasp: "It appears as what gives plentitude and vivacity to our life," and paradoxically, our Thing is conceived as something inaccessible to the other and at the same time threatened by him." (Zizek, 1993, p.203).

Now, ironically, many "foreigners" who have lived precariously as 'intruding' unwelcome presences, threatened in many cases with deportation, work in healthcare and homecare facilities where they are experiencing a different precarity. Their inability to appreciate the "nation qua thing" notwithstanding, they are identified as essential workers and are prevented from leaving the jobs. Their bod- 
ies, which once faced deportation are now locked in place. In another place, Nancy, reflecting on the moment he was informed that he needed a heart transplant to survive, found that nothing, in his words, "would allow me to disentangle the organic, the symbolic, and the imaginary, or the continuous from the interrupted." (Nancy \& Hanson, 2002, p.13). If we locate the pandemic as an interruption to all lives and seek to assess its implication for "foreign" lives, we have the very same discursive ambiguities to try and disentangle. Thus, Nancy goes on to ask "How does one become for oneself a representation?" He raises a question that bears on the changing situation of the precarious migrant who has been re-interpellated as a necessary presence (after having been cast as an unwelcome intruder) and is thus forced to face a different kind of precarity.

As to what is faced, it is an untimely death. Sitting at an intersection of historical time, bio-medical time, personal time and policy-making time, precarious migrants remain in a situation in which their lack of control over their lives is owed to a different arrangement of forces. Their new precarious situation sits in the midst of what is a historically recent re-inflection of the presentation of life/death based on a technological calculus of "which life should be prolonged." Precarious migrant workers, whether they work in the food and hospitality industries, hospitals, or elderly care homes, are enlisted in a workforce organized "to defer death," a situation that tragically, may hasten theirs.

\section{References}

Barthes, R. (1977). Roland Barthes by Roland Barthes (trans. Richard Howard). New York: Hill and Wang.

Bazin, A. (1971). An Aesthetic of Reality: Cinematic Realism and the Italian School of liberation. In What is Cinema (trans. Hugh Gray) (pp.3-19). Berkeley: University of California Press.

Benton, A. (2020). Border Promiscuity, Illicit Intimacies, and Origin Stories: Or what Contagion's Bookends Tell us About New Infectious Diseases and a Racialized Geography of Blame. Somatosphere, 6 March.

DeMicco, F. J. (2017). Medical Tourism and Wellness: Hospitality Bridging Healthcare (h2h). Burlington, ON: Oakville Apple Academic Press.

Derrida, J., \& Dufourmantelle, A. (2000). Of Hospitality. Stanford, CA: Stanford University Press.

Fregonese, S., \& Ramadan, A. (2015). Hotel Geopolitics: A Research Agenda. Geopolitics, 20(4), 793-813.

Kracauer, S. (1995). The Mass Ornament: Weimar Essays. Cambridge, MA: Harvard University Press.

Lee, F. (2004). If Disney Ran Your Hospital: 9 1/2 Things You Would Do Differently. Bozeman: Second River Healthcare Press.

Luke, T. W. (2003). 'Codes, Collectivities, and Commodities: Rethinking Global Cities as Megalogistical Spaces.' In L. Krause and P. Petro (Eds.), Global Cities: Cinema, Architecture, and Urbanism in a Digital Age (pp.157- 174). New Brunswick, NJ: Rutgers University Press. 
McDowell, L., Batnitzky, A., \& Dyer, S. (2007). Division, Segmentation, and Interpellation: The Embodied Labors of Migrant Workers in a Greater London Hotel. Economic Geography, 83(1), 1-25.

Mbembe, A. (2019). Necropolitics. North Carolina: Duke University Press.

Mowitt, J. (2000). Trauma Envy. Cultural Critique, (46), 272-297.

Nancy, J.-L., \& Hanson, S. (2002). L'Intrus. CR: The New Centennial Review, 2(3), 1-14.

O’Brien, E. (2015). The Little Red Chairs. New York: Little Brown.

Persad, G., \& Emanuel, E. J. (2020). The Ethics of COVID-19 Immunity-Based Licenses ("Immunity Passports"). JAMA, May 06. DOI: 10.1001/jama.2020.8102

Pravinchandra, S. (2013). Hospitality for Sale, or Dirty Pretty Things. Cultural Critique, (85), 38-60.

Rancière, J. (2004). The Sublime from Lyotard to Schiller: Two Readings of Kant and their Political Significance. Radical Philosophy, (126), 8-15).

Rancière, J. (2008). Aesthetic Separation, Aesthetic Community: Scenes from the Aesthetic Regime of Art. Art \& Research: A Journal of Ideas, Contexts and Methods, 2(1). Retrieved from http://www.artandresearch.org.uk/v2n1/pdfs/ranciere.pdf

Rancière, J., \& Corcoran, S. (2014). Hatred of Democracy. London: Verso.

Rancière, J., \& Elliott, G. (2011). The Emancipated Spectator. London: Verso.

Rancière, J., \& Panagia, D. (2000). Dissenting Words: a Conversation with Jacques Ranciere. Diacritics, 30(2), 113-126.

Rinelli, L., \& Opondo, S. O. (2013). Affective Economies: Eastleigh's Metalogistics, Urban Anxieties and the Mapping of Diasporic City Life. African and Black Diaspora, 6(2), 236-250.

Roback, J. D., \& Guarner, J. (2020). Convalescent Plasma to Treat Covid-19: Possibilities and Challenges. JAMA, 323(16), 1561-1562. DOI: 10.1001/jama.2020.4940

Shapiro, M. J. (2006). The Sublime Today: Re-Partitioning the Global Sensible. Millennium, 34(3), 657-681.

Stein, R. (2010). Disposable Bodies: Biocolonialism in The Constant Gardener and Dirty pretty Things. In P. Willoquet-Maricondi (Ed.), Framing the world: Explorations in Ecocriticism and Film (pp.101-115). Charlottesville, VA: University of Virginia Press.

United States Army Corps. (2020). Alternative Care Sites. Retrieved from https://www.usace.army.mil/coronavirus/alternate-care-sites/

Vergès, F. (2019). Capitalocene, Waste, Race, and Gender. e-flux Journal \#100 - May 2019. Retrieved from https://www.e-flux.com/journal/100/269165/capitalocene-wasterace-and-gender/

Zizek, S. (1993). Enjoy Your Nation as Yourself. In S. Zizek, Tarrying with the Negative: Kant, Hegel, and the Critique of Ideology. Durham, NC: Duke University Press. 